\title{
THE CHALLENGES OF CONSTRUCTING THE CONNECTIVITY BETWEEN INDONESIA AND MALAYSIA IN THE MALACCA STRAIT
}

\author{
Awani Irewati \\ Research Center for Politics, \\ Indonesian Institute of Sciences, Jakarta, Indonesia \\ Email:irewatiawani@yahoo.co.id
}

\begin{abstract}
One of the strategic and crustal sea lanes in Asia Pacific is the Malacca straits that separates the opposing coasts, between the Indonesia's island of Sumatera and the Malay Peninsula. This dynamic strait has pushed the pulse of maritime economy of the two countries No exception for people to people relationship have been closely intertwined long time ago. In this case, Medan and Dumai of Sumatera Island in Indonesia are the two cities which have traditionally established people to people interaction with Penang and Melaka cities of Malaysia. This kind of interaction have been formalized under the framework of IMT-GT and the ASEAN Community. By the two frameworks, this interaction is put under the pillar of people to people connectivity. In the context of these two cooperation, there are three elements inherent in the connectivity concept, namely "infrastructures", "institutions" and "people to people". Medan and Dumai of Sumatera island still continue to build up the desired connectivity as the maritime corridor remains a major challenge for strengthening the connectivity between Malaysia and Indonesia. This paper aims at scrutinizing the main quest, which focuses on the challenges faced by Indonesia in constructing the maritime connectivity with Malaysia in the Malacca Strait. Through field research of IMT-GT context and the qualitative analysis, the paper is in favor of the argument that the Indonesia's maritime corridors (Dumai and Medan) have not built adequately. In this regard, the government should streamline the management system linked to the internal connectivity issue.
\end{abstract}

Keywords: Connectivity, Malacca Strait, ASEAN, Border Studies

\section{Abstrak}

Salah satu jalur laut strategis dan kerak di Asia Pasifik adalah selat Malaka yang memisahkan pantai-pantai yang berseberangan, antara pulau Sumatera di Indonesia dan Semenanjung Melayu. Selat dinamis ini telah mendorong denyut nadi ekonomi maritim kedua negara. Tidak terkecuali hubungan orang ke orang telah terjalin erat sejak dulu. Dalam hal ini, Medan dan Dumai dari Pulau Sumatera di Indonesia adalah dua kota yang secara tradisional menjalin interaksi antar orang dengan kota Penang dan Malaka di Malaysia. Interaksi semacam ini telah diresmikan di bawah kerangka kerja IMT-GT dan Komunitas ASEAN. Dengan dua kerangka kerja, interaksi ini diletakkan di bawah pilar konektivitas orang ke orang. Dalam konteks kedua kerja sama ini, ada tiga elemen yang melekat dalam konsep konektivitas, yaitu "infrastruktur", "lembaga" dan "orang ke orang". Medan dan Dumai dari pulau Sumatera masih terus membangun konektivitas yang diinginkan karena koridor maritim tetap menjadi tantangan utama untuk memperkuat konektivitas antara Malaysia dan Indonesia. Makalah ini bertujuan untuk meneliti pen- 
carian utama, yang berfokus pada tantangan yang dihadapi Indonesia dalam membangun konektivitas maritim dengan Malaysia di Selat Malaka. Melalui penelitian lapangan konteks IMT-GT dan analisis kualitatif, makalah ini mendukung argumen bahwa koridor laut Indonesia (Dumai dan Medan) belum dibangun secara memadai. Dalam hal ini, pemerintah harus merampingkan sistem manajemen yang terkait dengan masalah konektivitas internal.

Kaca Kunci: Konektivitas, Selat Malaka, ASEAN, Kajian Perbatasan

\section{INTRODUCTION}

The Malacca Strait is one of the busiest shipping and trade lanes in the world, which passes through the geography of Indonesia, Malaysia and Singapore (Calamur, 2017). Peninsular Malaysia and east coast of Sumatera Island are entirely traversed by the Malacca Strait. Both countries' position in the Malacca Strait has supported them to build up closer connectivity through cross-border trade, social and cultural.

In the east coast of Sumatera Island, there are cities like Banda Aceh, Medan, Dumai, and so forth which are directly linked to the Malacca Strait, while the Peninsular Malaysia has Penang, Melaka and so forth. Both countries along with Thailand have established sub-regional cooperation in the I990s, namely Indonesia-Malaysia-Thailand Growth Triangle (IMT) (ADB (Asian Development Bank), 20I7). This sub-region cooperation is believed to be in favor of stimulating their mutual economic benefits to attain a common purpose.

Efforts to build land connectivity tends to be more advanced than to build maritime connectivity; for instance, a sub-regional cooperation namely Greater Mekong Subregion (GMS) is relatively more prominent and running smoothly to build up their continental connectivity because the GMS countries are not separated by the sea. Efforts to build up land infrastructures, institutions and people to people connectivity are relatively easier than a maritime connectivity. Besides, a strong political willingness of the governments seems to be the key factor to attain a successful connectivity development.

There are three fundamental factors in implementing the connectivity concept. Firstly, infrastructure connectivity which could make the movement of people, goods, services and so forth much easier among countries. Secondly, institutional connectivity that will strongly need coordinating process among various tasks forces of the governmental institutions from each member states. Thirdly, people to people connectivity that becomes the basic factor needed for all social interactions, both intra-state and inter-state.

However, the implementation of connectivity in the Strait of Malacca has become a major concern of Malaysia, Thailand, and Indonesia. Since the beginning, these countries, in fact, have already emphasized the importance of maritime connectivity for their mutual economic interests. However, Indonesia has been the only country that is separated by the sea (Malacca Strait) from the two neighboring countries, Malaysia and Thailand. Indonesia seems to be the country which is lag behind from its two neighboring countries. The main cause is about the sea connectivity, particularly, infrastructure and institutional connectivity between Indonesia and its neighbors has not well constructed yet.

Figure I. Cross Strait Traffic in the Malacca/ Singapore Straits

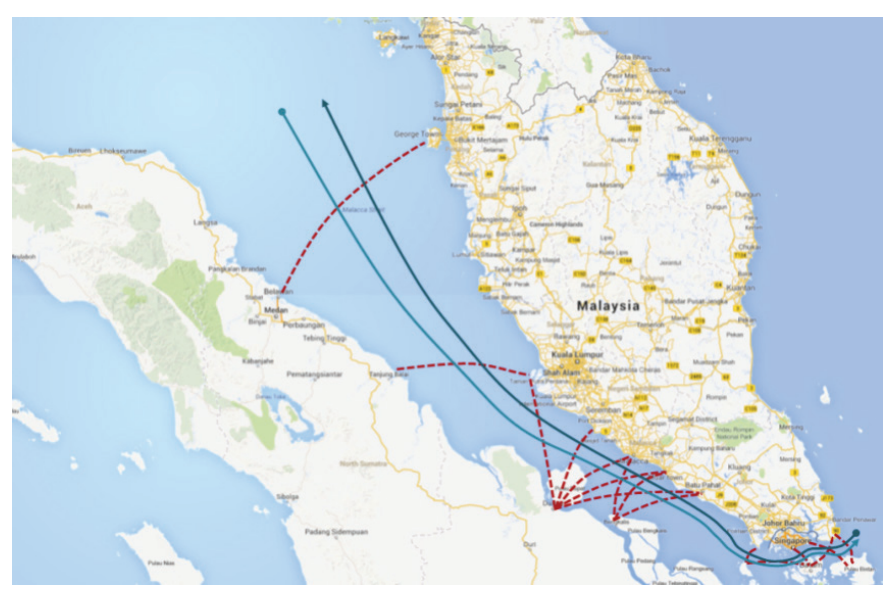

Source: StrasseLink, 20I4 
On the contrary, Thailand and Malaysia which relatively have no major barrier are more advantageous since they are mostly connected by the mainland. It is realized that building maritime connectivity between countries is relatively more difficult and costly. This is because constructing a connectivity over the sea requires high accuracy in taking high technological and technical calculation with, which is costly and takes quite a long time. With Sumatera Island is separated from northern Malaysia and southern Thailand, ideally there should be a bridge connecting Sumatera, Malaysia and Thailand. This paper would highlight the challenges of constructing the maritime connectivity between Indonesia and Malaysia in this Strait. The main reasons of choosing this connection are as follow: I) Both are located in the Strait of Malacca, which is an international shipping route, and part of China's Maritime Silk Road, 2) it is part of the ASEAN's 42 Ports under Master Plan on ASEAN Connectivity (MPAC), 3) the two corridors become the prospective connecting line to Malaysia that could distribute the Indonesia's export commodities.

Figure I shows how congested the Malacca Strait is, especially Dumai that has some travel destinations to Malaysia, namely Port Dickson, Malacca, Port Klang, and so forth. Meanwhile, Medan via Belawan Port also has connectivity with Penang. People to people connectivity between these two regions has been ongoing since a long time ago. These two regions (Dumai and Medan) have become two determinant regions in which their people have close relationship to Peninsular Malaysia. To what extent these two regions of Indonesia could take some benefits from their maritime connectivity in the Strait of Malacca will become interesting findings. Furthermore, this paper will also assess Indonesia's preparedness of "Tol Laut" (sea toll) development in the western part of Indonesia, especially in the Strait of Malacca. Before doing that, the paper would provide a brief explanation about the strategic position of the Malacca Strait in general, and to some extent the benefits that could be gained by the two regions (Dumai and Medan).

\section{THE STRATEGIC POSITION OF THE MALACCA STRAIT}

The Malacca Strait is a waterway connecting the Indian Ocean and the South China Sea heading to the Pacific Ocean. It runs between the east coast of Sumatra and the west coast of Peninsular Malaysia and extreme southern Thailand to the east. This strait covers an area of about 25,000 square miles or 65,000 square km (Encyclopaedia Britannica Online, n.d.). The strait is stretching about 550 nautical miles, with six chokepoints along the strait. The widest part of the strait reaches I6o miles (between North Sumatra and Thailand), ${ }^{\mathrm{I}}$ and the narrowest part of it reaches II miles (between lyu Kecil and Tanjung Piai) in the south (Irewati, 20Ir; Luhulima, 2007).

What becomes the Malacca strait so important for the global navigation is the strait still provides the shortest navigational route for world shipping from East Asia to Europe. This also means that the shorter shipping route, the cheaper traders pay for the expenses. Compared to other alternative routes like the Sunda and the Lombok Straits, the Strait of Malacca is relatively safe in time and in cost for international shipping. Passing through the Sunda Strait will be an alternative option for tankers, but with rigid calculation. According to Jia, this strait has difficult waterway, limited depth, and an active volcano, so that all tankers have to be more cautious. Besides, there are numerous oil drilling platforms to the north of Western Java, (Guoxing, 2002) hence tanker or shipping vessels should be highly cautious in passing through this strait.

The Lombok Strait-Makasar Strait (ALKI II) does not feature serious navigational hazards along the navigational channel but the routes require an additional of three and a half days navigating at full commercial speed of I4-I6 knots." In other words, the Lombok Strait is actually a strait with a relatively safest waterway for big vessels because "it is wider, deeper and less congested than the Strait of Malacca"

I Between We Island of Sumatra and the Isthmus of Kra on the mainland. The strait derived its name from the trading port of Melaka (formerly Malacca)-which was of importance in the I6th and I7th centuries-on the Malay coast (Encyclopaedia Britannica Online, n.d.). 
Figure 2. Malacca Strait Vessel Transits 2000 - 2017

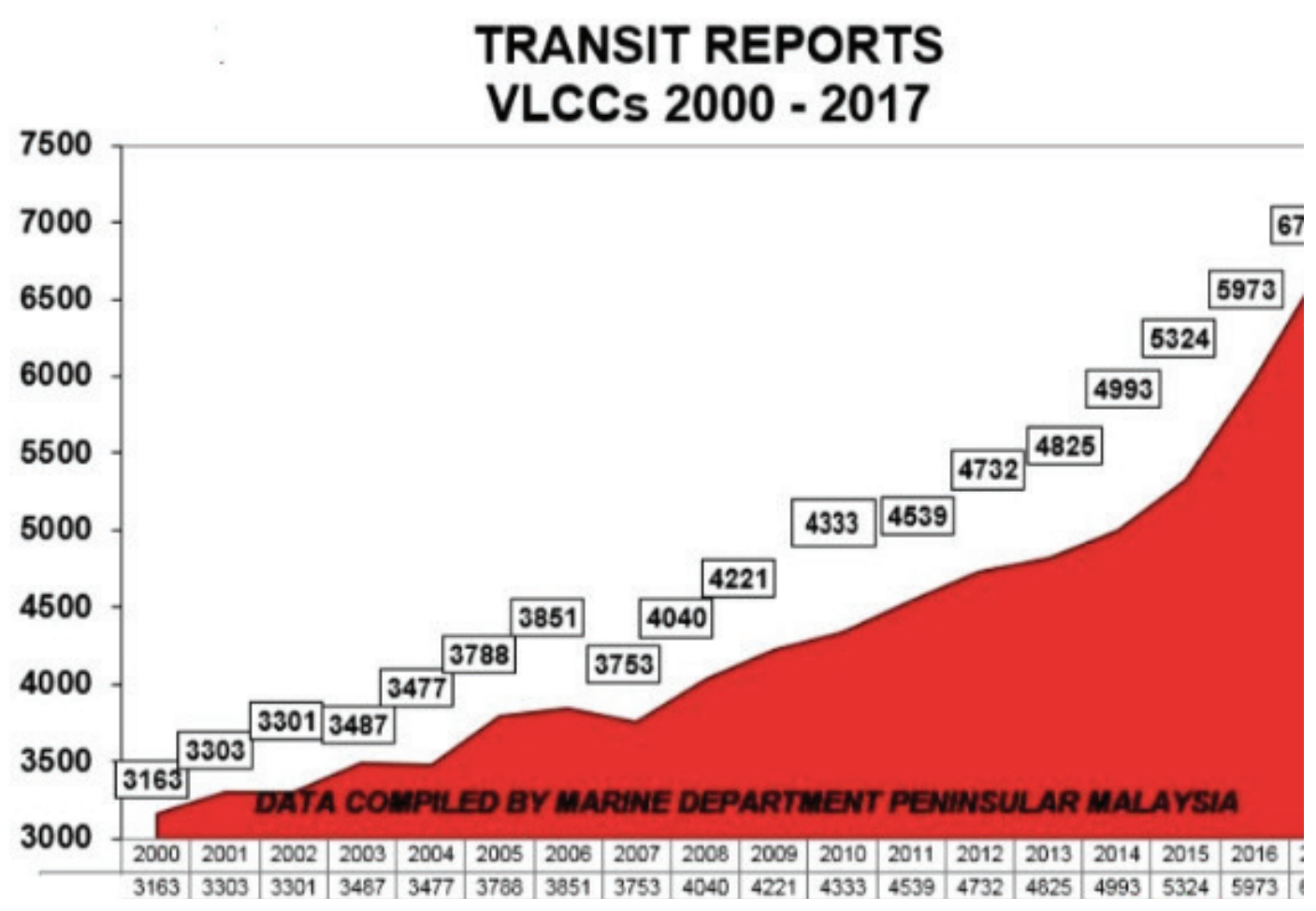

Source: Guoxing, 2002.

(Guoxing, 2002). However, in this context, there will be more expensive for the shipping route expense. Accordingly, most of tankers have always taken a waterway route based on a calculation of their lowest cost. It is not surprising that the Malacca Strait still becomes the prioritized waterway option other than the Strait of Sunda and the Strait of Lombok.

The data presented on previous page (Figure I) is mainly related to vessel transits to Malaysia in the Malacca Strait, especially the density line between One Fathom Bank to the north and lyu Kecil to the south. Since this line has been one of the most density transit link in the strait, it should genuinely provide some advantages for regions along the shipping line, especially regions of Indonesia. The current figures compiled by the Nippon Maritime Center (NMC) informed that 80,980 vessel transits in 2015 with over $300 \mathrm{gt}$ is passing from Europe to Asia, and this is only $2 \%$ increase compared to the 79,344 transits in 2014 (Hand, 2016). ${ }^{2}$

2 This Hand's article informs that the data reported by the NMC in Singapore since the year 2000 has received data from the Marine Department of Malaysia's STRAITREP reporting system. And the statistic has been
In more detailed picture, Figure 2 shows how crowded the shipping line (One Fathom Bank -lyu Kecil) by passing through this line (shown by the red colored area at the top). At the Malaysia's side, it is connected to Port Klang, Port Dickson, Malacca and so forth. At the Indonesia's side, it is related to Medan, and Dumai. Additionally, if we look at to the south line, there is Iyu Kecil Island (the outermost island) which is very close to Karimun Island. This is also shown by the red colored area at the bottom showing another shipping traffic density.

Further, from Figure 3 of the vessel traffic movement, we can get a clear picture of tracing vessels passing in the Strait of Malacca. In pursuit of updating information about which vessel is going or which port is the transit destination or final destination is now could be checked from the online picture.

calculated by numbering vessels passing from One Fathom Bank to the north and lyu Kecil Island to the south. 
Figure 3. Shipping Traffic Density in Malacca Straits in 2019

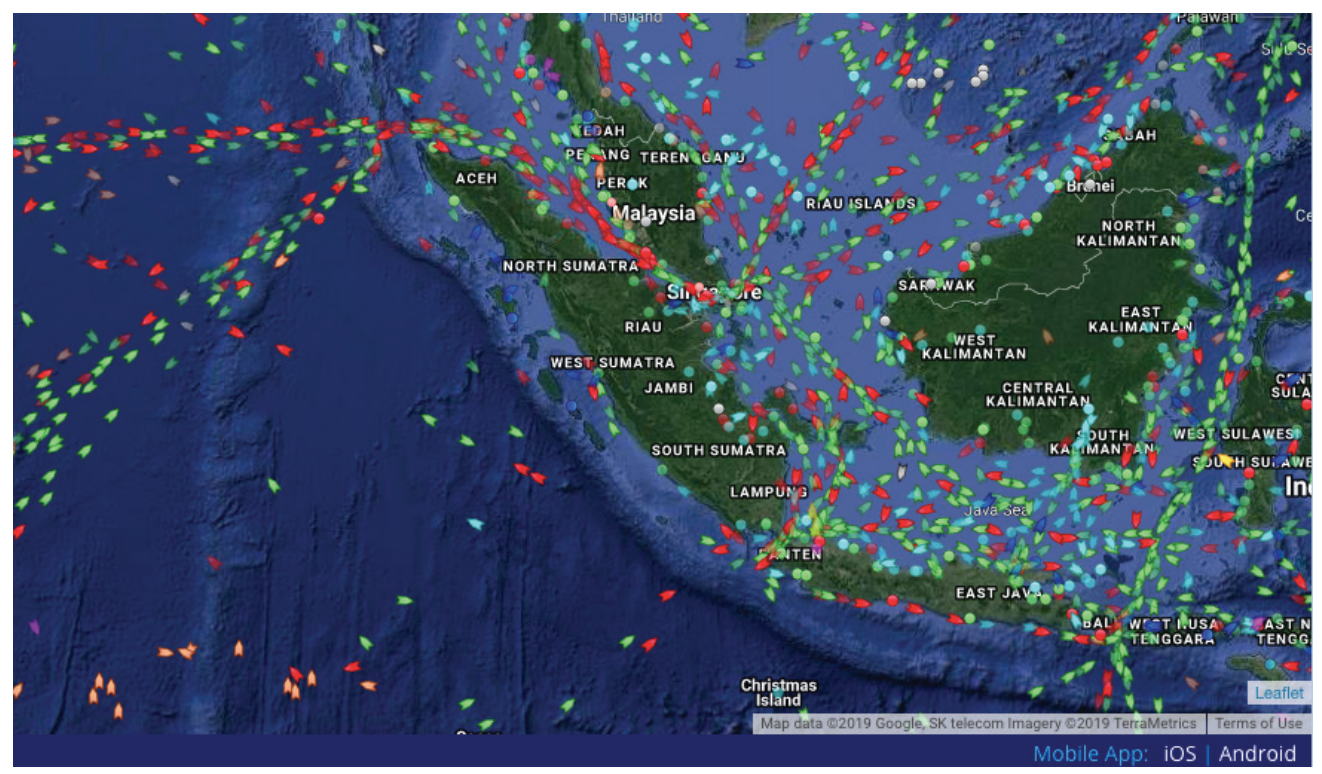

Source: Live Tracking AIS (marinevesseltraffic.com, 20I9)

The Malacca Strait has also become one of the most critical chokepoints to the world's oil trade. This strait occupies the most second rank of the 8 critical chokepoints after the Strait of Hormuz. Data provided in the latest picture of Figure 4 shows general mapping of these 8 narrow chokepoints to the world's oil trade supply.
The table below presents the data taken from the period of 2009 to 2013 , for the world's crude oil supply. These figures show how important the Strait of Malacca chokepoint is for oil supply lines in the world. One important matter is that there are eight chokepoints that mutually affect one another. If one chokepoint

Figure 4. The 8 Narrow Chokepoints Throughout the World

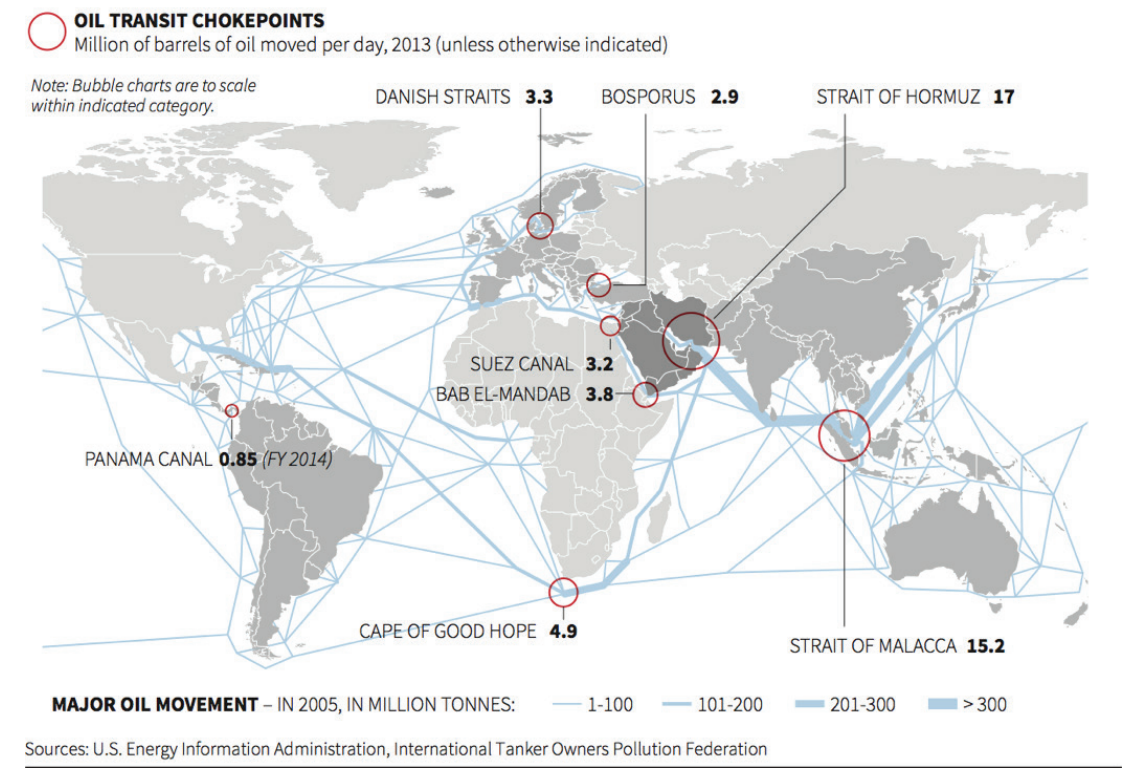

Source: (Bender, 2015) 
Table I. Volume of crude oil and petroleum products transported through world chokepoints and the Cape of Good Hope, $201 \mathrm{I}-2016$ (million b/d)

Table 1. Volume of crude oil and petroleum products transported through world chokepoints and the Cape of Good Hope, 2011-16 (million b/d)

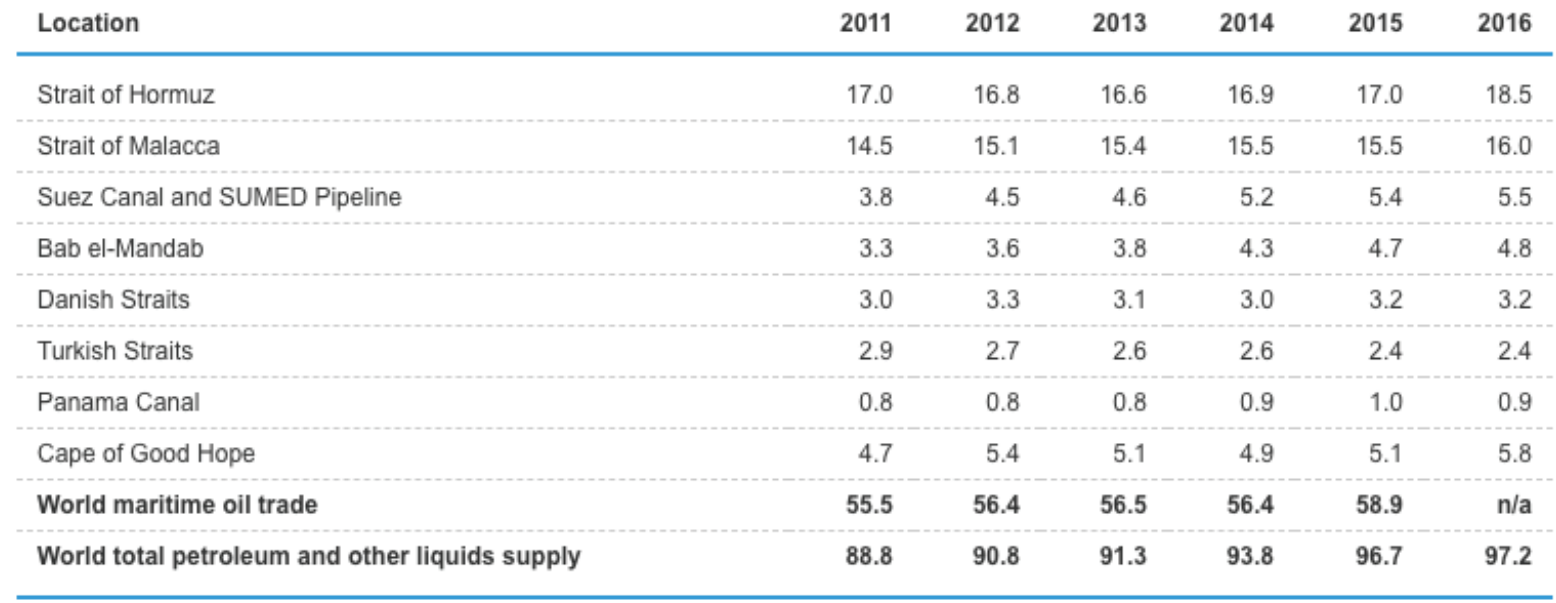

Note: Data for Panama Canal are by fiscal year

Sources: U.S. Energy Information Administration analysis based on Lloyd's List Intelligence, Panama Canal Authority, Argus FSU, Suez Canal Authority, GTT, BP Statistical Review of World Energy, IHS Waterborne, Oil and Gas Journal, and UNCTAD, using EIA conversion factors. ${ }^{4}$

Source: (U.S EIA, 20I7)

is disturbed, then it will influence the other chokepoints. If the Malacca Strait is interrupted, then it will also disrupt other trade channels. This leads the Malacca Strait to have a considerable strategic value. A source states that "World chokepoints for maritime transit of oil are critical parts of global energy security. About $63 \%$ of the world's oil production moves on maritime routes. The Strait of Hormuz and the Strait of Malacca are the world's most important strategic chokepoints by volume of oil transit" (Noer \& Gregory, I996, pp. 80-8I)

Chokepoint means "a narrow passage, such as a strait, through which shipping must pass."3 Another source states "Chokepoint is a common concept in transport geography, as it refers to location that limits the capacity of circulation and cannot be early bypassed, if at all. This implies that any alternative to a chokepoint involves a level of detour or use of an alternative that translate into significant financial costs and delays" (Rodrigue, 2004).

3 Thesaurus, chokepoint is: (i). A narrowing that reduces the flow through a channel; (ii). a point of congestion or blockage; "the bridge is always a chokepoint at rush hour” (TheFreeDictionary.com, n.d.).
Therefore, if blocking the chokepoints in these two straits, even for temporarily, could shake the supply of world energy cost and prices. Chokepoints in the Malacca Strait become vulnerable zone for all vessels, especially for oil tankers and container ships, because they are subject to pirates, terrorist attacks, shipping accidents and so forth. Throughout the Malacca Strait and Singapore Strait, there are six chokepoints that all shipping has to make a notice before passing each of them (Table 2). The six chokepoints have different depth condition, namely: One Fathom Bank (chokepoint I), Pulau Rupat (chokepoint 2), Pulau Karimun and Johor (chokepoint 3), Phillips Channel (chokepoint 4), Buffalo Rock (chokepoint 5), and pulau Batuberhanti (chokepoint 6).

Table 2. The Chokepoints in the Malacca Strait Singapore Strait

\begin{tabular}{llll}
\hline No. & Choke Points & Width & Depth \\
\hline 1. & One Fathom Bank & $1,391 \mathrm{~m}$ & $23,3 \mathrm{~m}$ \\
\hline 2. & Pulau Rupat & $3,704 \mathrm{~m}$ & $25 \mathrm{~m}$ \\
\hline 3. & Pulau Karimun and Johor & $2,965 \mathrm{~m}$ & $28,1 \mathrm{~m}$ \\
\hline 4. & Phillips Channel & $1,600 \mathrm{~m}$ & $22,5 \mathrm{~m}$ \\
& & and $800 \mathrm{~m}$ & \\
\hline 5. & Buffalo Rock & $532 \mathrm{~m}$ & $20 \mathrm{~m}$ \\
\hline 6. & Pulau Batuberhanti & $800 \mathrm{~m}$ & $21,2 \mathrm{~m}$ \\
\hline
\end{tabular}

Source: (Irewati, 20II, p. I86) 
Chokepoints I, 2 and 3 have the deepest and widest waterways, and fortunately Dumai (and Pulau Rupat) is precisely located in the groove of these chokepoints and has wide and deep zone of the Malacca Strait. While Medan is nearby One Fathom Bank. For the sake of the waterway security around the chokepoints, the users (of the Malacca Strait) have to pay much attention and take precautionary measures when in transit at a number of city ports, including Port of Dumai, Port of Medan, and surrounding waters (ICC-IMB, 20I6).

According to IMB report 2015, all ships have to maintain anti-piracy/robbery monitor when entering and transiting the Malacca Strait, especially if they approach and anchorage around the port areas (ICC-IMB, 20I6, p. I8). Moreover, this includes the water around the ports of Sumatera, such as Dumai, Belawan, Karimun, "even the number of ship attacks have decreased substantially due to an increasing and aggressive patrol by the littoral states authorities since July 2005”. ${ }^{4}$ At least seven sea ports of Indonesia have been reported as risky areas for attacks, namely Tanjung Priok, off Bintan Island, Dumai, off Karimun Island, Nipah, Pulau Takong Kecil, Medan/Belawan anchorage and surrounding waters. Again, Dumai and Medan are the two ports located in between the pathway of One Fathom Bank - Pulau lyu Kecil, which becomes dense traffic in the Malacca Strait.

\section{CONCEPTUAL MEANING OF 'CONNECTIVITY' IN THE STRAITS OF MALACCA}

In general (based on definition from TheFreeDictionary.com), the notion of connectivity is the ability to connect and maintain connection between two or more points in telecommunication system; the quality or condition of being connected or connective. In particular, the definition of connectivity currently refers to building common economic efforts by two or more countries on the basis of geographic proximity.

4 The littoral states refer to three neighboring states, namely Indonesia, Malaysia, Singapore (ICC-IMB, 20I6)
It is the ASEAN vision to create the unity of mosaic of economic growth among the members in pursuit of regional integration. In dealing with the implementation of connectivity program, "Master Plan on ASEAN Connectivity/MPAC" (adopted by 20I0, then by 2025) provides the pathway of countries in the pursuit of common economic goals, integrated and inclusive economic growth. In other words, it is the ASEAN countries commitment of constructing its intra-regional linkages through its sub-regional cooperation (i.e IMT-GT, BIMP-EAGA, etc). Through overland transport linkages, for example, they will give benefits for countries like Cambodia, Lao PDR, Vietnam and Myanmar and other isolated inland and under developed regions (ASEAN, 20II, p. I8). Besides, this would generate shared benefit among them and help to reduce economic gap within ASEAN.

Accordingly, ASEAN has set up the key elements to afford ASEAN connectivity, namely physical connectivity (transport, ICT, energy), institutional connectivity (Trade liberalization and facilitation, Investment and services liberalization and facilitation, Mutual recognition agreements/arrangements, Regional transport agreements, Cross-border procedures, Capacity building programs), and people to people connectivity; Education and culture, tourism (ASEAN, 20II, p. I9).

A scholar named Nathalie Fau (2013) states "One of the MPAC objectives is to enhance regional connectivity by promoting subregional initiatives, which usually focus on less developed areas of the ASEAN region with less developed infrastructures. Although it sounds pessimistic, in one case, it did work for the sub-regional connectivity of ASEAN Mainland, namely GMS (Greater Mekong Subregion).

In the context of the Malacca Strait, the implementation of connectivity concept actually has been conducted through subregional cooperation frameworks, namely IMT-GT (Indonesia-Malaysia-Thailand Growth Triangle), which was established in the mid of I99os.The development of land-based connectivity between Thailand-Malaysia has 
made well progress, while the development of maritime-based connectivity (between Indonesia-Malaysia, and Indonesia-Thailand) is somewhat less progress.

Building maritime connectivity corridor seems to remain a physical cross border barrier for an archipelagic country like Indonesia (see Map below). In the context of IMT-GT, constructing physical connectivity between Indonesia on the one side, and Malaysia and Thailand on the other side, over the Straits of Malacca also faces more complicated and costly efforts. Meanwhile the density of Malacca Straits as the worldwide busiest shipping route could be another potential advantage for Sumatera island if the maritime connectivity (Medan-Penang, and Dumai-Melaka) by Ro-Ro ferry could function soon.

Figure 5. Cross Border Connectivity in The Malacca Strait

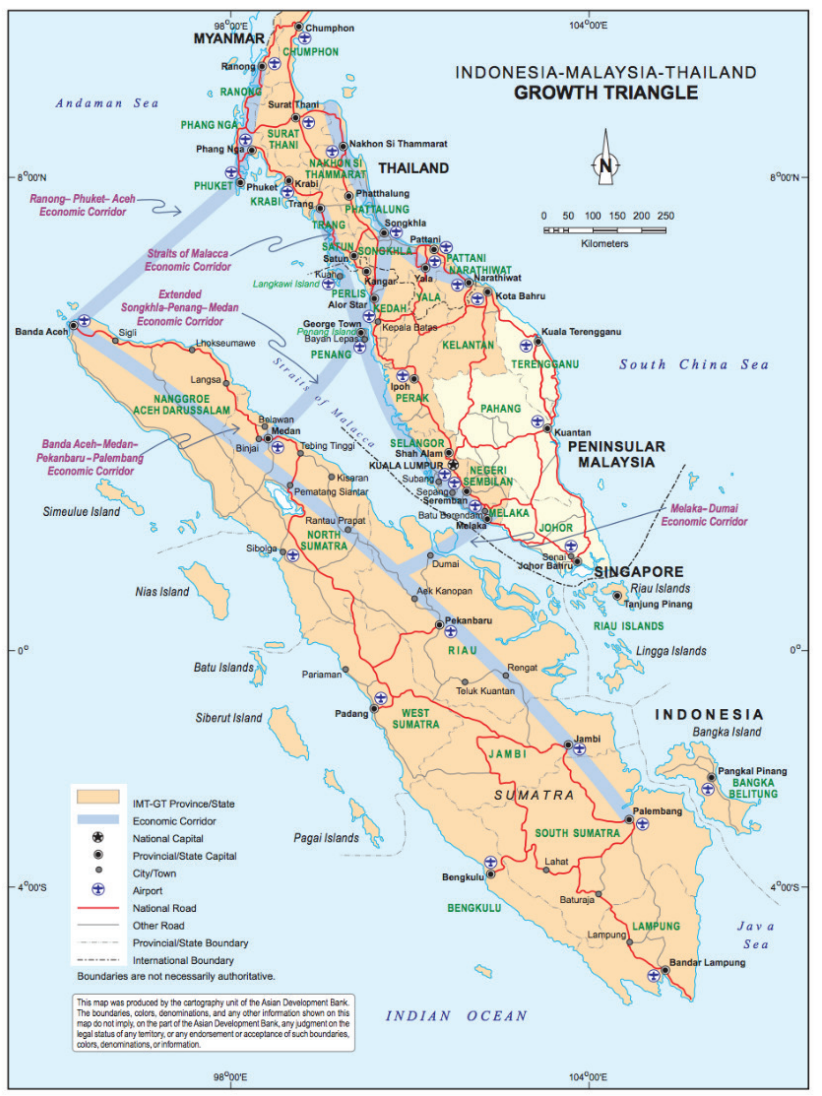

Source: (ADB (Asian Development Bank), 20I2)

It is reasonable among the neighboring countries who have geographical proximity, close historical, cultural and linguistic ties to construct a grouping of sub-regional economic cooperation with 'growth triangle' model, ${ }^{5}$ namely IMT-GT. This model actually becomes one of the basic natural pre-requisites towards an economic integration within ASEAN framework. However, all the things above will not work well without having an existed connectedness among the countries. This paper, therefore, focuses only on the connectivity construction of the east coast of Sumatera Island, especially at the two coastal cities, Medan and Dumai.

Figure 5 shows the five economic corridors that are identified under IMT-GT context as follow: I) Banda Aceh-Medan-Dumai-Palembang Economic Corridor; 2) Dumai-Melaka Economic Corridor; 3) Medan-Penang-SongkhlaPhatthalung-Nakhon Si Thammarat; 4) Strait of Malacca Economic Corridor; 5) Ranong-PhuketBanda Aceh Economic Corridor. Only two of these corridors are directly related to maritime economic corridor in the Strait of Malacca, namely Medan-Penang link and Dumai- Melaka link. For Indonesia, the two maritime corridors become the potential economic corridors which connect Indonesia's economic interests to the rest countries of IMT-GT. For this purpose, the two governments of Indonesia and Malaysia have followed up these maritime connectivity planning by RO-RO ferry scheduled at the end of $2019 .{ }^{6}$ The functioning of the maritime corridors through the Malacca Straits will be a pilot project as well as a model for a sub-regional cooperation of the IMT-GT covering two areas

5 Darryl G. Waldron (I997) explains that the 'growth triangle' concept was formally introduced in 1989 by $\mathrm{Mr}$. Goh Chok Tong then Deputy Prime Minister of Singapore. At the first time, it was the mission of the Singapore Manufacturers Association to propose a seminar themed investment promotion between Singapore and Malaysia in I989. Then it was followed by forming the Johor Singapore Joint Committee on Investment. Then, Prime Minister Lee Kuan Yew met with President Suharto of Indonesia to propose forming Singapore-Johor-Riau Growth Triangle (SIJORI). Since then, this 'growth triangle' model of economic cooperation has been generating another growth triangle in the Malacca Strait, like IMT-GT. This such cooperation is basically characterized by a common anatomy and purpose. See also (Nadalutti, 2015).

6 The governments of Indonesia and Malaysia already held "the Ist Sub-Committee of Ro-Ro Dumai-Malaka Task Force Meeting," at Dumai $14^{\text {th }}$ November 2019 (detik.com, 20I9). 
of connectivity, namely land and maritime connectivity.

\section{THE CHALLENGES FOR BUILDING THE MARITIME CONNECTIVITY IN INDONESIA}

\section{A. The Regulations on Maritime Affairs}

The latest legislation on maritime affairs is Law No. 32 of 2014 on the Development of Maritime Sector. It is then derived into a number of government as well as relevant ministries' regulations that are in line with its purposes, such as Government Regulation No. 82 Year 1999 Regarding the Transportation on Waters, Government Regulation No. 36 Year 2002 Regarding the Rights and Obligations of Foreign Ships in Conducting Innocent Passage through Indonesian Waters and Beyond.

In relation to the interests of Indonesia in the Strait of Malacca, the route of One Fathom Bank - Little lyu Island has become a serious concern for Indonesia and Malaysia. Some regulations that are directly related to this case are Law No. I7 Year 2008 Regarding the Shipping/Voyage, Government Regulation No. 36 Year 2002 Regarding the Rights and Obligations of Foreign Ships in Conducting Innocent Passage through Indonesian Waters and Beyond. As for Malaysia, there is Law No. I Year 1983 Regarding the Ratification of An Agreement between Indonesia and Malaysia on the Regime of the Archipelago State Law and the Rights of Malaysia over Territorial Seas, the Archipelago Waters as well as the Air Space over Territorial Seas, the Archipelago Waters and Indonesian Territory Which is Located Between Eastern and Western Parts of Malaysia.

In order to support the implementation of the Tol Laut policy of President Joko Widodo, it is important to develop and strengthen the maritime connectivity, especially those related with the development of infrastructure, institutional and people to people connectivity. The capacity on infrastructure connectivity becomes the first priority that should be strengthened and improved, especially connectivity in international shipping lanes like the Malacca Strait. The two port cities in Sumatera, which are Medan and Dumai, strategically become the key ports designated to be part of the foreland The purpose of the Tol Laut concept is to create an effective sea connectivity in which ships can sail regularly from western to eastern parts of Indonesia (Prihartono, 20I5).

\section{B. The Challenges for Dumai - Melaka Connectivity}

Out of 24 strategic Ports that are designed to support Tol Laut, five of them are Hub Ports while the remaining are Feeder Ports. Port of Medan becomes one of the Hub Ports that is in line with Ports of Tanjung Priok, Tanjung Perak, Makassar, and Bitung. However, Port of Dumai is not included into the Feeder Ports. Although it is just a regional port, its strategic location has enabled it to become inter-state shipping port. As aforementioned, Dumai becomes Dumai-Melaka Economic Corridor under IMT-GT, and now is improved to meet (and match) the standard of supporting international port.

The distance between Dumai and Melaka connectivity is actually shorter than the one between Penang and Medan. The Maritime transportation will operate four times a week (Tuesday, Wednesday, Thursday, Friday, and Saturday) from Port of Dumai to Port of Dickson operated by Indomal Express and Malaysia Express. This shipping lane reflects high dynamics of cross border people's mobility in the two 
Figure 6. Dumai-Melaka Economic Corridor Connectivity

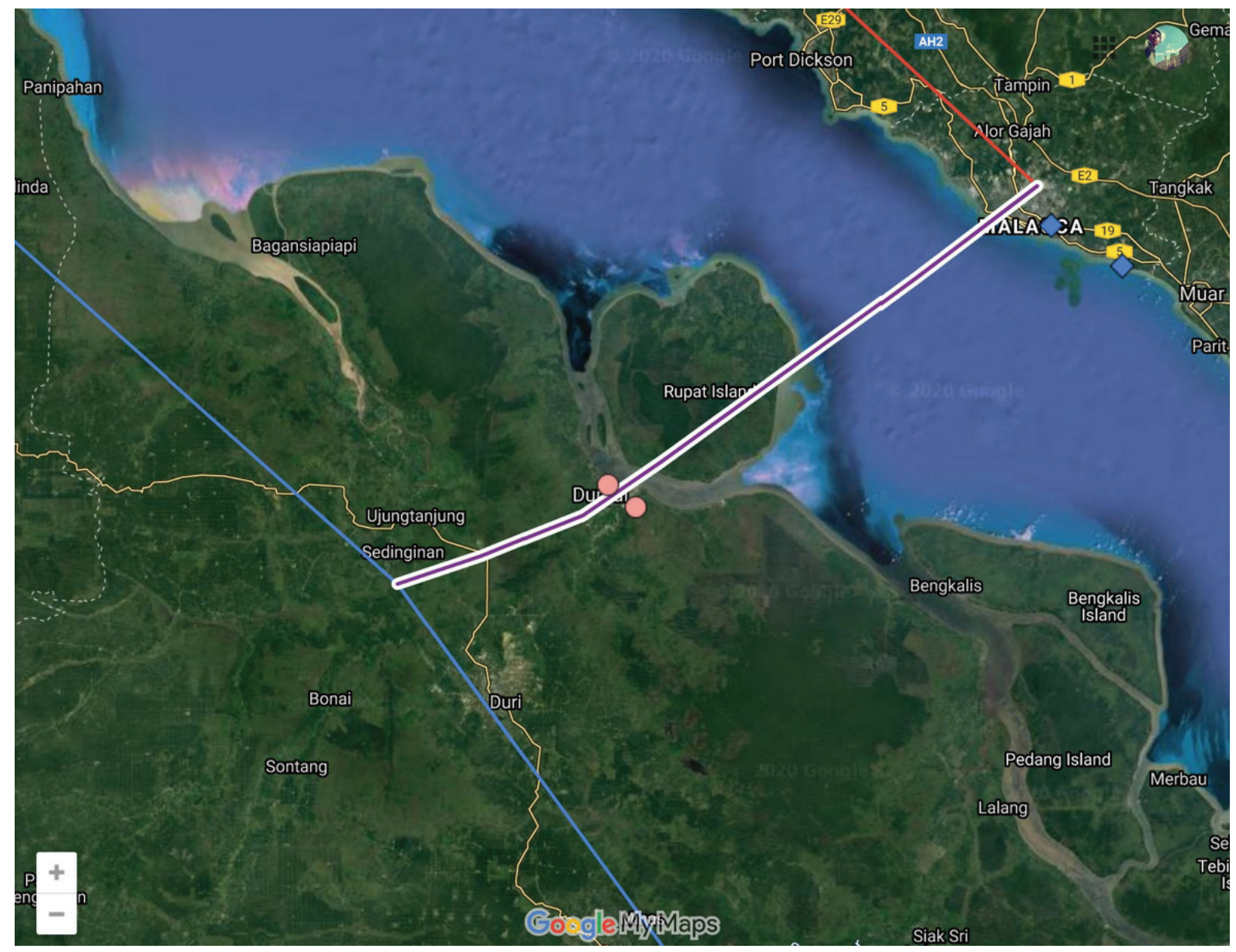

Source: (Google, n.d.)

countries. However, this voyage schedule does not include container vessels.

The Port of Dumai has a significant role in domestic transportation along the east side of Sumatera Island, linking several ports in providing services for people, goods trading, and logistic supply. In addition, the Port of Dumai isa meeting point of two corridors, between Aceh-Palembang Economic Corridor and Dumai-Melaka Economic Corridor. With such position, Dumai (through Port of Dumai) has a significant role in connecting the economic interests of Sumatera Island and Peninsular Malaysia. The Port of Dumai notably handles some cargoes i.e. dry bulk, general cargoes, and petroleum cargoes.

Dumai is a rapidly growing city. It is known as an Oil City with Chevron and
Pertamina as the oil processing companies there. Moreover, there are a number of oil palm plantations, mostly owned by Malaysia's investors. This sector generates job opportunities for local people; therefore, they can earn a living. Lacking tourist attractions in Dumai has caused many people there visit Melaka for having fun and recreation. For Melaka, Dumai plays an important role as a gateway to absorb the tourists, workers, and businesses to Malaysia. It is about 2 hours by ferry, which is not a big obstacle for people. This short visit provides business opportunities for Melaka's tourism sector.

The fact that a large number of immigrants who stay and work in Dumai, especially expatriates working in Chevron and others from outside Dumai, has 
prompted local authorities to make an effort to meet their daily needs. In this case, Melaka supplies a great deal of goods such as snacks, soft drink, medicines, as well as household appliances.

Imported food and beverages submerge some traditional markets and shopping centers in Riau offering cheaper prices than those of local products. The Dumai Chapter of the Department of Industry and Trade has attempted to limit the number of imported food and beverages from Malaysia from entering the port in Dumai. In this regards, local government has restricted the imported products from coming into Riau due to lower selling prices than the local ones. Therefore, this is all about market demand and supply, which depends on the people purchasing power over these imported products that offer cheaper price but with good quality.

As conveyed by Jamalus, the Head of the Dumai Chapter of DISPERINDAG (Department of Industry and Commerce), there were 220 kinds of imported food and beverage products in Dumai in the year of 2012 but another 220 products are still needed by the community due to their relatively cheaper prices. The official further stated "in order for local products to be not marginalized amidst the outpouring of imported products, we adopted a policy to restrict the amount of imported food and beverages from coming in" (fokusriau. com, 2012). Despite the import restrictions has been imposed, the products from Malaysia are still widely circulated in many supermarkets. This is actually a compelling evidence of the real competition in the era of ASEAN Economic Community. Therefore, the Local Government and the Chamber of Local Commerce should provide mentoring and continuous training about the standardization of product making process to all entrepreneurship sectors.

Another challenge is Dumai prone to the rampant smuggling of Malaysian commodities (i.e. onion, sugar, flour and so forth) through the port of Dumai, particularly through Rupat Island (the foremost islands in the Strait of Malacca). This smuggling has a negative impact for local commodities and violates Article Ioz letter A on the customs of carrying sugar without manifest of cargo (Republika, 20I6). There are many entrances to Dumai, especially Rupat Island, for this kind of smuggling activities. Dumai is geographically located behind Rupat Island and is not directly facing the high seas of the Strait of Malacca. Therefore, it is critical to overcome any smugglers by enhancing the security systems of the ports and the entire coastal regions of Sumatera.

All cities on the east coast of Sumatra Island, especially Dumai and Medan/ Belawan, are the cities on the edge of the Strait of Malacca which are prone to any illegal activities as the strait is one of the world's busiest shipping lane.

\section{The Challenges for Medan - Penang Connectivity}

Medan becomes the biggest maritime connectivity point in North Sumatra which is connected to Penang Malaysia. In the past, the existing sea connectivity between Medan to Penang conducted by ferry Ro-Ro (roll on-roll off) under fairly high frequency of shipping. This reflected that people between the two cities have come in and out through the corridor Medan-Penang and their mobility are actually quite high. Nevertheless, the mobility through this maritime corridor is recently dispensed because this ferry crossing is not considered as a lucrative business.

Other than this crossing, it has operated ships crossing from Penang - Langsa (Aceh) which are scheduled on Tuesday and Thursday for departure from Penang and scheduled on Mondays and Wednesdays for departure from Langsa, each of which only for one trip journey. The trip can be completed within 5-6 hours at a speed of 26 knots. The crossings schedule that only operates twice a week from each city of 
departure signifies the interest of people on crossing the sea remains low.

However, many passengers travel through the Penang-Medan connectivity by flight. Some air carriers such as Lion and AirAsia operates in this lane. Many people of North Sumatera travel to Penang for various reasons such as business, studies, medical treatment and even family reunion. The most popular reason for traveling to Penang is to get a medical examination (medical treatment) because of some considerations such as good customer services, lower cost, and shorter distance. Therefore, Malaysian Government has offered a healthcare package under the Medical Tourism promotion. This provides business opportunity for Penang, Malaysia, by promoting a list of participating health care facilities and their medical specialties.

Furthermore, Penang becomes the entrance of North Sumatera's export commodities, and this surely provides benefits for both sides. From the side of Sumatra, Indonesia, export commodities such as vegetables (cabbage, carrots, green beans, round coconut, turmeric, ginger, potato, tomato, avocado), and pinang seeds can increase the amount of revenue for North Sumatra Province. Today, there is an increasing market demand of these food stuff and groceries to support the logistical needs of hotels, hospitals, and a variety of culinary tourism in the island of Penang.

With the Penang-Medan Corridor Connectivity, the flow of trade transactions in the agricultural and livestock sectors have increased. Penang's products have been widely marketed in Medan's shopping centers such as Maxim Yang Lim Plaza, Carrefour, and "Maju Bersama". In order to nurture the business, the Indonesia Consulate in Penang has organized an event "Business Matching" between SumatraPenang, which was held at St Giles Wembley in Penang in early July 2016 (Jurnal Asia, 20I6).
The main objective of this event is to bring together young entrepreneurs from both sides in order to share information and business networks as well as to establish significant cooperation. The event was attended by 120 entrepreneurs engaged in the sectors of food, garments, leather products, cosmetics, tourism and advertising, spices, handicrafts and so on. In this event there is also a signing of the $\mathrm{MoU}$ between the Chamber of Commerce of North Sumatra and Perdasama Penang (Union of Malaysia Entrepreneurs and Traders).

In addition, the transportation cost of Medan's exports via Penang will be about 25-30 percent lower than the same one via the Port of Singapore. Medan becomes an export gate, for all products of Sumatera, to Malaysia, and then continue to Singapore Port as a transshipment hub in Asia. Therefore, this maritime connectivity (Ro-Ro shipping) is highly important for freight shipments and is expected to be improved for the sake of the continuity of export shipments within this corridor. This physical connectivity seriously becomes the fundamental connectivity that is needed for the business affairs between the countries, especially for the Small and Medium Enterprises level. Additionally, there is flight connection from Medan to Penang, which takes 25 flights per day. These flights are served for people who need a quick mobility in dealing with their own business affairs.

This maritime connectivity is also needed for people who always make family visits between the two countries. Such family visits and other social interaction; for instance, gathering for cultural discussion, cultural exhibition, study exchange, and so forth have established people to people connectivity which is basically supporting and reviving the economic corridor between the countries. The Medan-Penang corridor connectivity will be more effective if the time schedule of maritime voyage can be further enhanced. 
According to a scholar, there are numerous Indonesian's people selling herbal medicine (jamu), which attracts many buyers in Penang.7 This picture reflects how familiar the Malaysians with jamuto keep their body healthy. At the same time, this jamu business, mostly taken by SMEs, provides wide opportunity for SMEs to get benefits. Again, these SMEs usually take maritime voyage in doing business transaction. However, sometimes they have to face the ferry is not operating due to technical problem, and this condition is not conducive.

Another challenge of Indonesia's Ports performance is mostly related to the dwelling time as a "key" problem which has a direct impact to the Terminal Handling Charge (THC).There are long bureaucratic processes that the importers should follow such as the examination procedure of container through customs, immigration, quarantine, security, BPOM, Majelis Ulama Indonesia etc. Each of these sections take uncertain time depending on the problem it faces, and sometimes the businessman has to bribe the officer in order to shorten the time of container assessment. ${ }^{8}$ This dwelling time has caused more cost in the Terminal Handling Charge, so that unfortunately the Indonesia's Ports have become less competitive than the Malaysia's Ports.

As a comparison, the Ports of Malaysia and of Singapore have a very short time for the container's assessment (less than 2 days for dwelling time). Each of procedural section is handled through "one stop services". Because of this efficient working system, their Terminal Handling Charge have been less expensive.

\footnotetext{
$7 \quad$ Presented by responden in the Focused Group Discussion on "IMT-GT Subregional Cooperation and Its Impact to the Development of ASEAN Connectivity" at USU Campus, Medan, May 2016.

8 Stated by responden (from the private sector) in the Focused Group Discussion on "IMT-GT Subregional Cooperation and Its Impact to the Development of ASEAN Connectivity" at USU Campus, Medan, May 2016.
}

\section{CONCLUSION}

The Straits of Malacca is geographically undeniable to be part of the concept of Tol Laut, and on the other side it plays as one of the most critical shipping lanes across Asia Pacific. Indonesia especially the east coast of Sumatra and Peninsular Malaysia have become an important gateway for the entrance of international vessels to the Malacca Strait. Therefore, Sumatra Island and Peninsular Malaysia could indeed take the advantages of their location on the edge of the strait.

Maritime economic development that is being implemented in Indonesia is largely determined by the establishment of cross-land and sea connectivity. In fact, land connectivity is more well developed than maritime connectivity. Therefore, the maritime connectivity being promoted by Jokowi under the sea toll policy is aimed at improving inter-island connectivity, in order to accelerate the path of the domestic economy from the western region of Indonesia to the eastern region.

Indonesia's membership in sub-regional cooperation programs such as the IMT-GT can strengthen the realization of these ideals. The Connectivity Program of IMT-GT includes 3 important pillars namely physical, institutional and people to people. In terms of physical connectivity, maritime corridors are being built between Sumatra and Malaysia especially Dumai-Melaka Corridor and Medan-Penang Corridor.

In the context of physical pillar, these two corridors are still lag behind the land economy corridors that were well built between Malaysia and Thailand. This terrestrial economic corridor has relatively faster progress compared to the maritime corridor. This is a challenge for Indonesia (also Malaysia) to immediately strengthen its maritime corridor path, especially its infrastructure.

If maritime connectivity can function effectively, as targeted in the IMT-GT, this can strengthen Indonesia's economic expansion to reach the next corridors at the northern ASEAN level and to the global level. This is the corridor developed in the IMT-GT cooperation 
that can be maximized by businesspeople from Sumatra, through the two corridors. Hopes for the functioning of the Roll on Roll off Ferry Ship will soon be able to transport goods and people in a larger volume than before.

In the context of institutional pillar, regulations at the central and regional level need to be streamlined to ease the business affairs, including the strengthening of SMEs. A new way of paradigm should be based on the spirit of professionalism. In this case, the implementation of the new way of paradigm regarding economic development, needs collaborative efforts among all actors of government, local governments, state-owned enterprises, private enterprises and the people.

The last pillar, people to people connectivity between the two countries has actually been built long time ago, because of their strong cultural, social and economic ties. This created their fundamental connectedness in all segments. Therefore, this kind connectivity plays a strong fundamental linkage for the two other pillars of connectivity.

\section{REFERENCES}

ADB (Asian Development Bank). (20I2). IMTGT Implementation Blueprint 2012-2016. https://www.adb.org/sites/default/files/ page/34235/imt-gt-implementation-blueprint-20I2-20I6-july-2oI2.pdf

ADB (Asian Development Bank). (20I7). IMTGT Implementation Blueprint 20I7-202I. https://www.gica.global/resources/imt-gtimplementation-blueprint-2017-202I

ASEAN. (20II). Master Plan on Asean Connectivity. ASEAN Secretariat. https://www.asean.org/ storage/images/ASEAN_RTK_2OI4/4_Master_Plan_on_ASEAN_Connectivity.pdf

Bender, J. (2015, April 2). These 8 narrow chokepoints are critical to the world's oil trade. Business Insider Australia. https://www.businessinsider. com.au/worlds-eight-oil-chokepoints-2015-4

Calamur, K. (2017, August 2I). High Traffic, High Risk in the Strait of Malacca. The Atlantic. https://www.theatlantic.com/international/ archive/20I7/o8/strait-of-malacca-uss-johnmccain/53747I/

detik.com. (20I9, November 4). RI-Malaysia Bertemu Bahas Persiapan Pelayaran Ro-Ro Dumai-
Malaka. detiknews. https://news.detik.com/ berita/d-4784219/ri-malaysia-bertemu-bahaspersiapan-pelayaran-ro-ro-dumai-malaka

Encyclopaedia Britannica Online. (n.d.). Strait of Malacca. Encyclopedia Britannica. Retrieved June 23, 2020, from https://www.britannica. com/place/Strait-of-Malacca

Fau, N. (2013). Poor Maritime Connectivity in the Straits of Malacca. IIAS The Newsletter, 63(Spring). https://www.iias.asia/the-newsletter/article/poor-maritime-connectivitystraits-malacca

fokusriau.com. (20I2, August 30). Disperindag Dumai akan Batasi Impor Produk. Fokus Riau. http:// www.fokusriau.com/berita-disperindagdumai-akan-batasi-impor-produk-.html

Google. (n.d.). IMT-GT Project Map. Google My Maps. Retrieved October 8, 20I6, from https://www. google.com/maps/d/viewer?mid=ITs4s2bixS bQScFMEd8pNALcU9HA\&hl=en_US

Guoxing, J. (2002). Asian Pacific SLOC security: The China factor. RAN Sea Power Centre.

Hand, M. (20I6, March 7). Malacca Strait transits grow $2 \%$ to record in 2015, boxships see dip in $\mathrm{H} 2$. Seatrade Maritime. https://www.seatrademaritime.com/asia/malacca-strait-transitsgrow-2-record-2015-boxships-see-dip-h2

ICC-IMB. (2016). Piracy and Armed Robbery Against Ships (ICC IMB Piracy and Armed Robbery Against Ships-20I5 Annual Report). ICC International Maritime Bureau. https://www. hellenicshippingnews.com/wp-content/ uploads/2016/02/2015-Annual-IMB-PiracyReport-ABRIDGED.pdf

Irewati, A. (20II). Dinamika Perbatasan Wilayah Laut di Selat Malaka Singapura. Jurnal Penelitian Politik, 8(2), I83-I95. https://doi.org/I0.I4203/ jpp.v8i2.472

Jurnal Asia. (20I6, July 4). KJRI Gelar GELAR "Business Matching” Sumut-Pulau Pinang. Jurnal Asia. https://www.jurnalasia.com/seremoni/ kjri-gelar-gelar-business-matching-sumutpulau-pinang/

Luhulima, C. P. F. (2007). Dimensi Keamanan Pelayaran di Selat Malaka-Singapura. In S. Dam (Ed.), Politik perbatasan: Masalah pengamanan lalu lintas pelayaran di Selat Malaka-Singapura. Lembaga Ilmu Pengetahuan Indonesia, Pusat Penelitian Politik.

marinevesseltraffic.com. (2019, December 3). Marine Traffic. Marinevesseltraffic.Com. https:// www.marinevesseltraffic.com/20I3/o4/ marine-traffic.html 
Nadalutti, E. (20I5). The Rise of Trans-Border Regions in Southeast Asia: Behind the Dynamics of Informal and Formal Integration Processes in the 'Indonesia-Malaysia-Singapore' Growth Triangle. The Pacific Review, 28(4), 607-630. https://doi.org/I0.I080/095I2748.20I5.IOI 2536

Noer, J. H., \& Gregory, D. (1996). Chokepoints: Maritime Economic Concerns in Southeast Asia. National Defense University Press Published in Cooperation with the Center for Naval Analyses.

Prihartono, B. (2015, April 30). Pengembangan Tol Laut Dalam RPJMN 2015-20I9 dan Implementasi 2015 [Badan Perencanaan Pembangunan Nasional]. https://www. bappenas.go.id/id/profil-bappenas/unitkerja/deputi-bidang-sarana-dan-prasarana/ direktorat-transportasi/contents-direktorattransportasi/pengembangan-tol-laut-dalamrpjmn-2015-20I9-dan-implementasi-2015/

Republika. (2016, June I2). Penyelundupan I5 Ton Gula Asal Malaysia Digagalkan. Republika Online. https://republika.co.id/berita/nasional/ daerah/ı6/o6/ı2/o8nljb335-penyelundupanI5-ton-gula-asal-malaysia-digagalkan
Rodrigue, J.-P. (2004). Straits, Passages and Chokepoints: A Maritime Geostrategy of Petroleum Distribution. Cahiers de Géographie Du Québec, 48(135), 357-374. https://doi. org/I0.7202/oII797ar

StrasseLink. (20I4). Straits. StrasseLink. http://www. strasselink.com/straits.php

TheFreeDictionary.com. (n.d.). Choke point. TheFreeDictionary.Com. Retrieved June 23, 2020, from https://www.thefreedictionary.com/ choke+point.

U.S EIA. (20I7, July 25). World Oil Transit Chokepoints. U.S. Energy Information Administration (EIA). https://www.eia.gov/international/ analysis/special-topics/World_Oil_Transit_Chokepoints

Waldron, D. G. (1997). Growth Triangles: A Strategic Assessment. Multinational Business Review, 5(I), 53 .

\section{Interview}

The Focused Group Discussion (Tim Perbatasan LIPI - interviewees) on "IMT-GT Subregional 
